\title{
Modifications in the Transformation Step of Commercially Available Site-directed Mutagenesis Kit Increase Its Price-performance
}

Atta Ahmad*, David F. Jahad, Hamzah Karimi, Mary A. Farwell, Jean-Luc Scemama and Cindy Putnam-Evans

Department of Biology, East Carolina University, Greenville, NC, USA

*For correspondence: ahmada@ecu.edu

[Abstract] Site-directed mutagenesis helps unravel the relationship between the structure and function of a protein at the level of amino acid contributions. Many techniques have been established to carry out site-directed mutagenesis on a daily routine. QuikChange II Site-Directed Mutagenesis $\mathrm{Kit}^{\mathrm{TM}}$ is one of such methods available commercially. But this kit is expensive. Here we describe modifications in the transformation step by reducing the usage of competent cells of this protocol that will increase its priceeffectiveness. Since the kit is used widely, these modifications might have global application.

Keywords: Site-directed mutagenesis, Transformation, DNA isolation, Competent cells, Chaperone proteins

[Background] Physiological function of a protein is meticulously controlled by its structure. Conformation changes in a protein from its native state have disastrous implications on human health (Carrell and Gooptu, 1998; Chiti and Dobson, 2006). For example, a single amino acid change in hemoglobin leads to sickle cell disease (Ingram, 2004) and a single amino acid change in $\alpha$-synuclein is the reason for familial parkinsonism (Krüger et al., 1998). Thus, study of amino acids in relation to protein structure and function is highly relevant and useful with respect to human health.

In 1982 Winter et al., devised a method for selective replacement of single amino acid in a protein, tyrosyl tRNA synthetase. In their site-directed replacement, they mutated Cys35 of the molecule to Ser and observed that single amino acid change caused reduction in the tyrosyl tRNA synthetase enzyme activity (Winter et al., 1982). Since then many different methods have been developed for achieving sitedirected mutagenesis of proteins. QuikChange mutagenesis method is one such method (Papworth et al., 1994; Braman et al., 1996). Further, in using QuikChange II Site-Directed Mutagenesis Kit ${ }^{\mathrm{TM}}$ from Agilent Technologies, the need for specific restriction sites and the strand status is completely eliminated and the process can be completed in a short period of time. However, QuikChange II Site-Directed Mutagenesis Kit is expensive and cost to product ratio is very high. In this study, we describe modifications in the transformation step of the protocol, which will significantly reduce the use of materials in carrying out each site-directed mutation and will also reduce the time taken in the whole process. These modifications will maximize the yield of QuikChange II Site-Directed Mutagenesis Kit and will significantly improve its price-performance ratio. 


\section{Material and Reagents}

1. Pipette tips (Fisher Scientific, many different sizes and types)

2. Bacteriological Petri Dishes $(100 \times 15 \mathrm{~mm})$ (Fisher Scientific, catalog number: 08-757-100D)

3. Falcon tube (Corning, catalog number: 352059)

4. $\mathrm{NaCl}$ (Fisher Scientific, catalog number: S671-3)

5. Tryptone (Sigma, catalog number: T7293-250G)

6. Yeast extract (Fisher Scientific, catalog number: BP14220-500)

7. Agar (Apex Chemicals and Reagents, catalog number: 20-248)

8. $\mathrm{MgSO}_{4}$ (Fisher Scientific, catalog number: M-63 75626)

9. $\mathrm{MgCl}_{2}$ (Fisher Scientific, catalog number: BP214-500)

10. Glucose (Fisher Scientific, catalog number: D16-1)

11. Ampicillin (Fisher Scientific, catalog number: BP1760-25)

12. Luria-Bertani Broth (Difco ${ }^{\mathrm{TM}}$ Becton and Dickinson, catalog number: 244610)

13. QuikChange II Site-directed mutagenesis kit with XL-super competent cells (Agilent Technologies, catalog number: 200523-5)

14. PureLink ${ }^{\mathrm{TM}}$ Quick Plasmid Miniprep kit (Thermo Fisher Scientific, catalog number: K210010)

15. Tris hydroxymethyl aminomethane hydrochloride (Fisher Scientific, catalog number: BP152-500)

16. LB-media (see Recipes)

17. SOC buffer (see Recipes)

18. Agar plates (see Recipes)

\section{Equipment}

1. Pipettes (Eppendorf North America)

2. Water bath (Fisher Scientific, catalog number: 15-462-15)

3. Incubator $37^{\circ} \mathrm{C}$ (Fisher Scientific, catalog number: 11-690-650D)

4. Shaker incubator (New Brunswick Scientific, model: classic C24, catalog number: M12470004)

5. Centrifuge swing bucket (Eppendorf, catalog number: AG 22331)

6. Tabletop fixed angle (Beckman Coulter Inc., catalog number: 367160)

7. Biospec-nano spectrophotometer (Shimadzu, catalog number: 206-26300-32)

8. Weighing scales (Mettler Toledo, models: AE240 and PE200)

9. $-80^{\circ} \mathrm{C}$ freezer (Thermo Fisher Scientific, model: ULT2586-4-A48)

10. $-20^{\circ} \mathrm{C}$ freezer (GE $20.8 \mathrm{cu}$. Ft. Top Freezer)

\section{Procedure}

A. Transformation of plasmid of choice into the XL1 blue cells 
1. Prepare LB media, LB-Agarose plates and SOC as described in the recipes section below. Procure QuikChange II Site-Directed Mutagenesis Kit and PureLink ${ }^{\mathrm{TM}}$ Quick Plasmid Miniprep kit.

2. Aliquot $\mathrm{XL1}$ blue super competent cells from QuikChange II Site-Directed Mutagenesis Kit ${ }^{\mathrm{TM}}$ or cell stock in 10 or $5 \mu \mathrm{l}$ sizes to prevent repeated freeze/thaw. Store at $-80^{\circ} \mathrm{C}$ until next use.

3. Start your circulating water bath and set its temperature at $42^{\circ} \mathrm{C}$. It is a good practice to use an additional external thermometer for monitoring temperature. Make sure its temperature is steady at $42{ }^{\circ} \mathrm{C}$ before going to Step $A 8$.

4. Place the LB-agar plate(s) containing desired antibiotics and SOC at $37^{\circ} \mathrm{C}$.

5. When ready for transformation thaw 10 or $5 \mu \mathrm{l}$ cells (or any volume from 1-20 $\mu \mathrm{l}$ ) on ice. Also, thaw your desired plasmid to be transformed on ice (for best results plasmid concentration should be $\sim 100 \mathrm{ng} / \mu \mathrm{l})$. This step takes $15-20 \mathrm{~min}$.

6. Transfer competent cells into a Falcon tube and mix $1 \mu$ plasmid with it.

7. Incubate on ice for 10 min without disturbance.

8. After incubation, immerse the falcon tube in the $42{ }^{\circ} \mathrm{C}$ circulating water bath for $30 \mathrm{~s}$. Check Step A3 for extra precautions before starting this step. If using a stationary water bath, keep moving the falcon tube in water to ensure uniform exposure to temperature.

9. Incubate the heat shocked sample on ice for $2 \mathrm{~min}$.

B. Plasmid amplification in XL1 blue cells

1. Add $300 \mu \mathrm{l} \mathrm{SOC}$ to transformed sample (Step A9 above) and incubate in shaker incubator for 60-90 min; with shaking at $250 \mathrm{rpm}, 37^{\circ} \mathrm{C}$.

2. Take $30 \mu \mathrm{l}$ from this SOC mixture and spread uniformly on the LB-agar-antibiotic plate(s) preincubated at $37^{\circ} \mathrm{C}$.

3. Incubate the plate(s) with your transformed material overnight at $37^{\circ} \mathrm{C}$. For best results don't exceed $16 \mathrm{~h}$ of incubation.

4. A successful transformation will produce a floor of transformed bacterial (XL1 cell) colonies.

5. Pick an isolated colony and inoculate $4 \mathrm{ml} \mathrm{LB}$ culture media containing desired antibiotics. This is your starter culture. Incubate it for 6-8 h or until the media is slightly turbid.

6. Inoculate a fresh $10 \mathrm{ml}$ LB-antibiotic media with $100 \mu \mathrm{l}$ starter culture and incubate overnight $(12-16 \mathrm{~h})$.

7. The next morning centrifuge the cells at $3,381 \times g$ for $20 \mathrm{~min}$. Discard the supernatant and store the cell pellet at $-20{ }^{\circ} \mathrm{C}$ until further use. To purify plasmid from these cells or to check the transformed plasmid is exactly as you desire, proceed to Procedure C.

C. Plasmid/DNA purification

1. When ready thaw the cell pellet stored at $-20^{\circ} \mathrm{C}$. Lyse the cell pellet and isolate the plasmid/DNA using your choicest method or a kit. For example, we used PureLink ${ }^{\mathrm{TM}}{ }^{\text {Quick Plasmid Miniprep }}$ kit to purify the transformed plasmid. 
2. Determine the concentration of the plasmid. We used $2 \mu \mathrm{l}$ plasmid on Shimadzu Biospec-nano spectrophotometer. The machine uses algorithm and automatically calculates the final concentration of DNA.

3. We recommend getting the plasmid sequenced to know the exact sequence of the plasmid before proceeding to the next step of your project.

4. Gel electrophoresis can be used to purify the plasmids further if needed.

\section{Data analysis}

The protocol described above reduces the amount of cells required to perform a transformation using the QuikChange Site-directed mutagenesis kit. The results (Figure 1) show similar cell colonies produced irrespective of the amount of XL1 blue cells used in transformation. The difference in the amount of purified plasmid DNA produced under both conditions was $<20 \%$ (Table 1). Therefore the modifications proposed in this protocol are going to increase the price-performance of QuikChange II Site-directed mutagenesis kit.

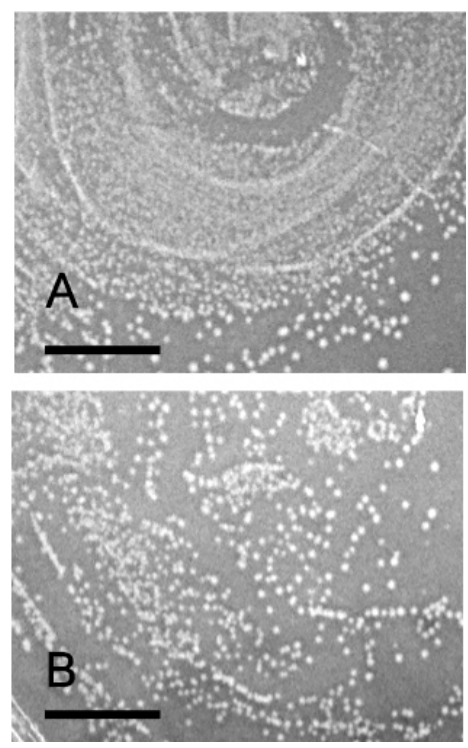

Figure 1. Bacterial colonies produced from transformation of $10 \mu \mathrm{l}(\mathrm{A})$ or $5 \mu \mathrm{l}(\mathrm{B}) \mathrm{XL1}$ blue cells with the same plasmid at the same concentration. Scale bars $=10 \mathrm{~mm}$.

Table 1. The concentration for purified plasmid produced by transforming 10 or $5 \mu \mathrm{XL1}$ blue cells

\begin{tabular}{cc}
\hline XL1 blue cells used in the experiment & $\left(\mathbf{A}_{260}-\mathbf{A}_{280}\right) \times \mathbf{5 0}$ \\
\hline $10 \mu \mathrm{l}$ & $58 \mathrm{ng} / \mu \mathrm{l}$ \\
$5 \mu \mathrm{l}$ & $49 \mathrm{ng} / \mu \mathrm{l}$ \\
\hline
\end{tabular}




\section{$\underline{\text { Recipes }}$}

1. LB-media

Dissolve $25 \mathrm{~g}$ of powdered broth (from Difco ${ }^{\mathrm{TM}}$ ) per liter of double distilled water, autoclave it, add ampicillin when it cooled $\left(\sim 60^{\circ} \mathrm{C}\right)$

2. SOC buffer

a. Autoclave $\mathrm{NaCl}(0.05 \%)$, Tryptone $(2 \%)$, Yeast extract $(0.5 \%)$ in double distilled water

b. Wait for it to cool and add the following filter sterilized compounds: $1 \mathrm{ml}$ of $1 \mathrm{M} \mathrm{MgSO}_{4}, 1 \mathrm{ml}$ of $1 \mathrm{M} \mathrm{MgCl}_{2}$ and $2 \mathrm{ml} 20 \%(\mathrm{w} / \mathrm{v})$ Glucose

C. Store at $4{ }^{\circ} \mathrm{C}$

3. Agar plates

a. Autoclave $\mathrm{NaCl}(1 \%)$, Tryptone (1\%), Yeast extract $(0.5 \%)$, agar $(2 \%)$ in double distilled water

b. Upon cooling, add ampicillin and pour ( $20 \mathrm{ml})$ into each plate. Let solidify (you can get away with $\sim 10 \mathrm{ml} /$ plate)

c. Store at $4{ }^{\circ} \mathrm{C}$ until use

Note: Transformation of plasmid, Plasmid amplification, Plasmid/DNA purification, Refer to Procedure section above.

\section{Acknowledgments}

We want to thank Golfers Against Cancer, Greensboro, NC for funding (award \# A15-0163-001). DFJ is supported by GAC.

Contribution: AA developed the idea, interpreted data and wrote the article. DFJ, HK and AA collected data. CPE, MAF and JLS provided reagents.

Competing interests: Authors declare no competing conflict of interest.

\section{References}

1. Braman, J., Papworth, C. and Greener, A. (1996). Site-directed mutagenesis using doublestranded plasmid DNA templates. Methods Mol Biol 57: 31-44.

2. Carrell, R. W. and Gooptu, B. (1998). Conformational changes and disease--serpins, prions and Alzheimer's. Curr Opin Struct Biol 8(6): 799-809.

3. Chiti, F. and Dobson, C. M. (2006). Protein Misfolding, Functional Amyloid, and Human Disease. Annu Rev Biochem 75: 333-366.

4. Ingram, V. M. (2004). Sickle-cell anemia hemoglobin: the molecular biology of the first "molecular disease"--the crucial importance of serendipity. Genetics 167(1): 1-7. 
5. Krüger, R., Kuhn, W., Müller, T., Woitalla, D., Graeber, M., Kösel, S., Przuntek, H., Epplen, J. T., Schöls, L. and Riess, O. (1998). Ala30Pro mutation in the gene encoding a-synuclein in Parkinson's disease. Nat Genet 18(2): 106-108.

6. Papworth, C., Greener, A. and Braman, J. (1994). Highly efficient double-stranded, site-directed mutagenesis with the Chameleon ${ }^{\mathrm{TM}}$ kit. Strategies 7: 38-40.

7. Winter, G., Fersht, A. R., Wilkinson, A. J., Zoller, M. and Smith, M. (1982). Redesigning enzyme structure by site-directed mutagenesis: tyrosyl tRNA synthetase and ATP binding. Nature 299(5885): 756-758. 